\title{
OPEN Molecular fusion of surfactant and Lewis-acid properties for attacking dirt by catalytic bond cleavage
}

\begin{abstract}
Marvin L. Frisch ${ }^{2,3}$ \& Sebastian Polarz ${ }^{1,2}$
The capability of ordinary surfactants in solubilizing hydrophobic compounds can come to a limit, if the extension of a contaminant is too large. An attractive goal is the development of surfactants which can actively reduce the size of dirt. Because strong Lewis acids are known to catalyze both bond formation and cleavage, an integration into the surfactant's molecular framework is tempting. Endgroup functionalized hepta-dentate ligands, which coordinate to metal ions preventing deactivation by hydrolysis over a broad range of $\mathrm{pH}$ values while maintaining strong Lewis-acidity, are herein presented. After proof of amphiphilicity and surfactant characteristics, catalytic properties are investigated for different reactions including the cleavage of proteins. The compounds perform better than benchmark catalysts concerning the attack of unreactive amide bonds. A study with two $\mathrm{Sc}^{3+}$ species as the active site, one non-amphiphilic, the other one being surface-active, underlines the positive effect of surfactant properties for boosting catalytic efficiency.
\end{abstract}

The main function of surfactants is amphiphilicity, meaning they are able to decrease the energy of interfaces. Interfacial activity is the key for numerous applications in research, industry and in everyday life. Surfactants are the crucial constituent in almost all detergents on the market. However, classical surfactants reach their limit when the extension of the contaminants is too large. Then, mechanical abrasion is a possibility for their removal. Cleaning by scrubbing can be difficult depending on the accessibility of the polluted surface, on its geometry, on its mechanical stability and many other factors. Another well-known approach is the use of additives, e. g. oxidation agents, in detergents. These additives are unspecific and may accelerate unwanted wear down of materials. Unfortunately, oxidants are often not successful for many organic contaminants on cookware resulting from the Maillard reaction, for instance. As a major drawback, dilution as a consequence of dissolution requires the use of a significant excess, when working with two different compounds separately. The collaboration of the two components, surfactant and additive, occurs by chance.

Thus, the implementation of an active entity capable of attacking dirt on a molecular level into a surfactant is a different concept because the simultaneous impact of both functionalities is programmed in the molecular framework. The implementation of a Lewis-acid into a surfactant would open up multiple possibilities beyond cleaning applications, e. g. in phase-transfer catalysis. Next generation surfactants possess additional properties beyond amphiphilicity ${ }^{1}$. In particular, the combination with catalytic properties has raised large interest. An important review has been published by Scarso et al. in $2019^{2}$. There are only a few reports on metal species or catalysts as an integral part of the surfactant's molecular architecture, for instance as a head group. This situation has not changed a lot since first original papers and reports on metallosurfactants have been published ${ }^{3-6}$.

A relevant catalytic mechanism relies on the activity of a strong Lewis acid in lowering the activation barrier for bond cleavage and bond formation ${ }^{7}$. Powerful Lewis acids are known from solid-state chemistry used in heterogeneous catalysts ${ }^{8-10}$. For the combination with a surfactant, one obviously seeks for homogeneous conditions and molecular type catalysts ${ }^{11}$, such as compounds containing metal atoms (e. g. Zn, Sc, Ti, Zr, Yb) preferentially in their highest oxidation state. However, the resulting electrophilic character leads to a problem in aqueous solution ${ }^{12}$. In alkaline conditions, in particular, the formation and precipitation of the corresponding metal hydroxides and oxy-hydroxides leads to an irreversible deactivation of the catalyst. There has been

\footnotetext{
${ }^{1}$ Institute for Inorganic Chemistry, Leibniz-University Hannover, Callinstrasse 9, 30167 Hannover, Germany. ${ }^{2}$ Department of Chemistry, University of Konstanz, Universitaetsstrasse 10, 78457 Konstanz, Germany. ${ }^{3}$ Institute of Chemistry, Technical University Berlin, Strasse des 17. Juni 124, 10623 Berlin, Germany. ${ }^{\circledR}$ email: sebastian.polarz@aca.uni-hannover.de
} 

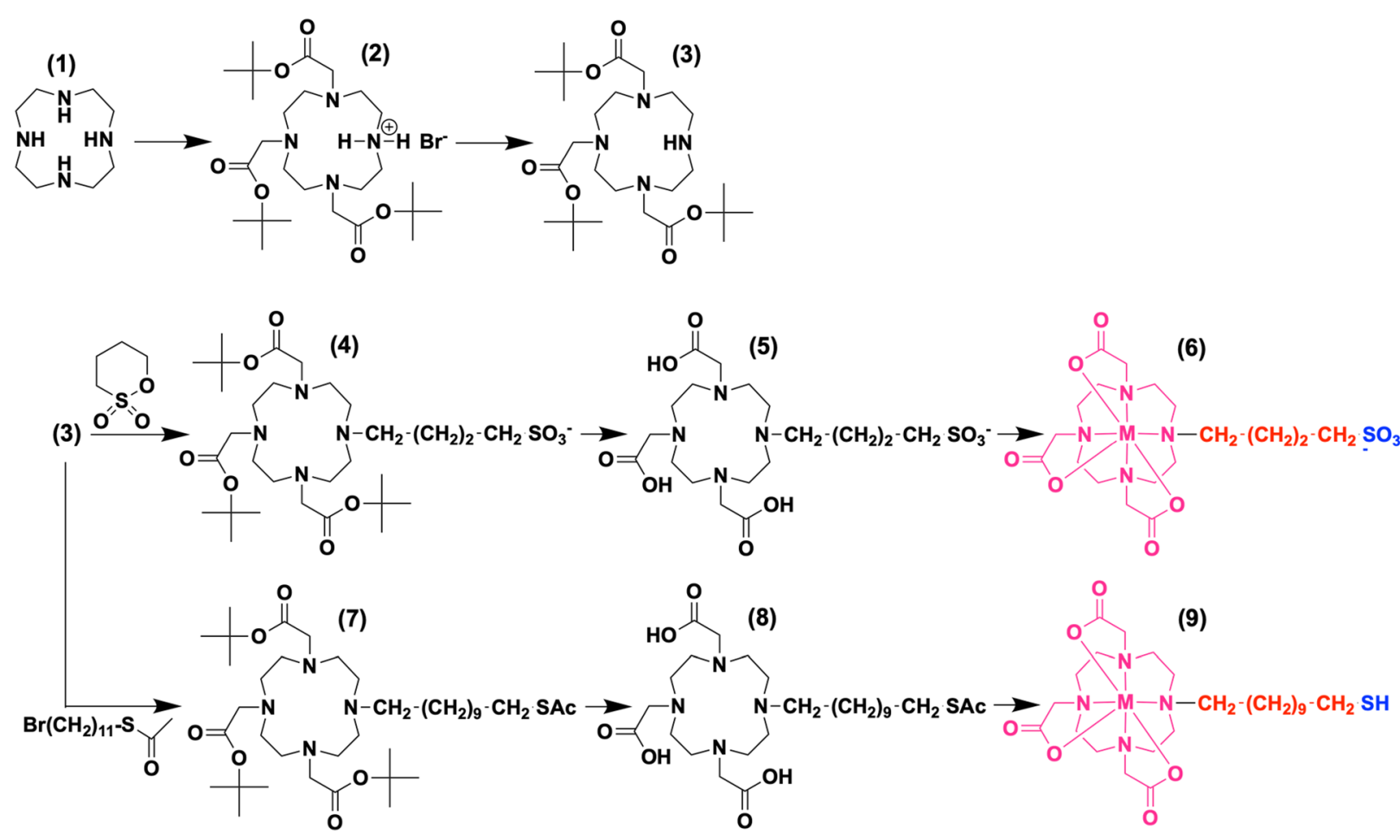

Figure 1. Synthesis routes to new surfactants with DO3A-metal complexes as constituents. (a) sulfonic acid terminated bolaform compounds $\mathrm{M}-\mathrm{DO} 3 \mathrm{~A}-\mathrm{C}_{4}-\mathrm{SO}_{3}$. (b) thiol terminated bolaform compound M-DO3A$\mathrm{C}_{11}-\mathrm{SH}$. Blue = hydrophilic; red = hydrophobic; purple = predominantly hydrophobic. $\mathrm{M}^{3+}=\mathrm{Ce}^{3+}(\mathrm{i}), \mathrm{Sc}^{3+}(\mathrm{ii})$, $\mathrm{Yb}^{3+}(\mathrm{iii})$.

substantial effort regarding the development of molecular Lewis-acid catalysts for an application in aqueous systems as outlined by Kobayashi in several seminal articles ${ }^{11,13}$. The most promising route for the stabilization of the metal centre is the coordination to multi-dentate ligands. Importantly, the electrophilicity has to remain sufficiently high. Beyond that, free sites at the metal centre for substrate coordination are still required.

Our goal are surfactants containing an active Lewis acid as a head group, which is stable even under alkaline conditions in aqueous media. Our group has presented novel amphiphilic compounds comprising a cyclen derivative modified by three acetic acid groups (DO3A) to which one alkyl group with adjustable chain length is attached $\left(C_{n}\right)^{14,15}$. We were interested in the special magnetic properties of DO3A- $C_{n}$ complexes with metals such as $\mathrm{M}=\mathrm{Mn}^{2+}, \mathrm{Co}^{2+}, \mathrm{Ni}^{2+}, \mathrm{Dy}^{3+}$. Lewis-acidic metals have not been used and catalytic properties have not been studied so far. Here, the ligand system is developed further and strong Lewis acids such as $\mathrm{Yb}^{3+}, \mathrm{Ce}^{3+}$ or Sc $^{3+}($ see Fig. 1) are coordinated, followed by a study of their amphiphilic properties and testing of their catalytic activities.

\section{Results}

The charge of the deprotonated ligand DO3A- $\mathrm{C}_{\mathrm{n}}$ is $(3-)^{14,15}$. In combination with a metal cation $\mathrm{M}^{3+}$, the charge reduces to (0), so does the solubility in water. $\mathrm{As} \mathrm{M}^{3+}\left(\mathrm{Yb}^{3+}, \mathrm{Ce}^{3+}, \mathrm{Sc}^{3+}\right)$ are preferred due to their enhanced electrophilicity compared to weaker Lewis acids (e. g. $\mathrm{Zn}^{2+}$ ), the introduction of an additional polar group becomes necessary for providing sufficient solubility in aqueous media. Surfactants with two head-groups on opposing sides of the hydrophobic chain are also called bolaform surfactants ${ }^{16,17}$.

Bola M-DO3A- $\mathrm{C}_{n}-\mathrm{SO}_{3}$ compounds. Sulfonic acid groups seem promising (Fig. 1) because of the low $\mathrm{pK}_{\mathrm{a}}$ value $(\approx-7)$ of $\left(-\mathrm{R}-\mathrm{SO}_{3} \mathrm{H}\right)$. Based on the experiences described above $\mathrm{e}^{14,15}$, a viable conclusion is that a zerocharged $\mathrm{M}^{3+}-\mathrm{DO} 3 \mathrm{~A}^{3-}$ entity is at least partially hydrophobic. If $\mathrm{M}^{3+}-\mathrm{DO} 3 \mathrm{~A}^{3-}$ adds to the hydrophobic block of a surfactant, a relatively short alkyl chain as a spacer to the sulfonic groups should be sufficient to evoke amphiphilic properties. Thus, DO3A- $\mathrm{C}_{4}-\mathrm{SO}_{3}(5)$ represents our first target compound (Fig. 1a). Further details about the synthetic steps are given in experimental part ${ }^{18}$. The most important step is reaction of the free base (3) in a ring-opening nucleophilic substitution with 1,4-butane sultone followed by the acid-catalysed deprotection. Characterization of the resulting organic ligand (5) was accomplished via NMR spectroscopy and mass spectrometry analysis, which are given in the Supporting Information in SI-1 +2 .

The final coordination of the metal centres $(5) \rightarrow(6)$ was proven by a combination of methods, which are summarized in SI-3. Electrospray ionization mass spectrometry (ESI-MS) is a very efficient technique for the characterization of metallosurfactants, as the metal often contributes a characteristic isotope pattern. Figure 2a,b shows two representative ESI-MS patterns for Ce-DO3A- $\mathrm{C}_{4}-\mathrm{SO}_{3}$ and $\mathrm{Sc}-\mathrm{DO} 3 \mathrm{~A}-\mathrm{C}_{4}-\mathrm{SO}_{3}$. For the diamagnetic complexes, e. g. Sc-DO3A- $\mathrm{C}_{4}-\mathrm{SO}_{3}, \mathrm{NMR}$ spectroscopy was feasible as an additional characterization technique (see Supporting Information Fig. SI-3). Attenuated total reflection infrared spectroscopy (ATR-IR spectroscopy) 

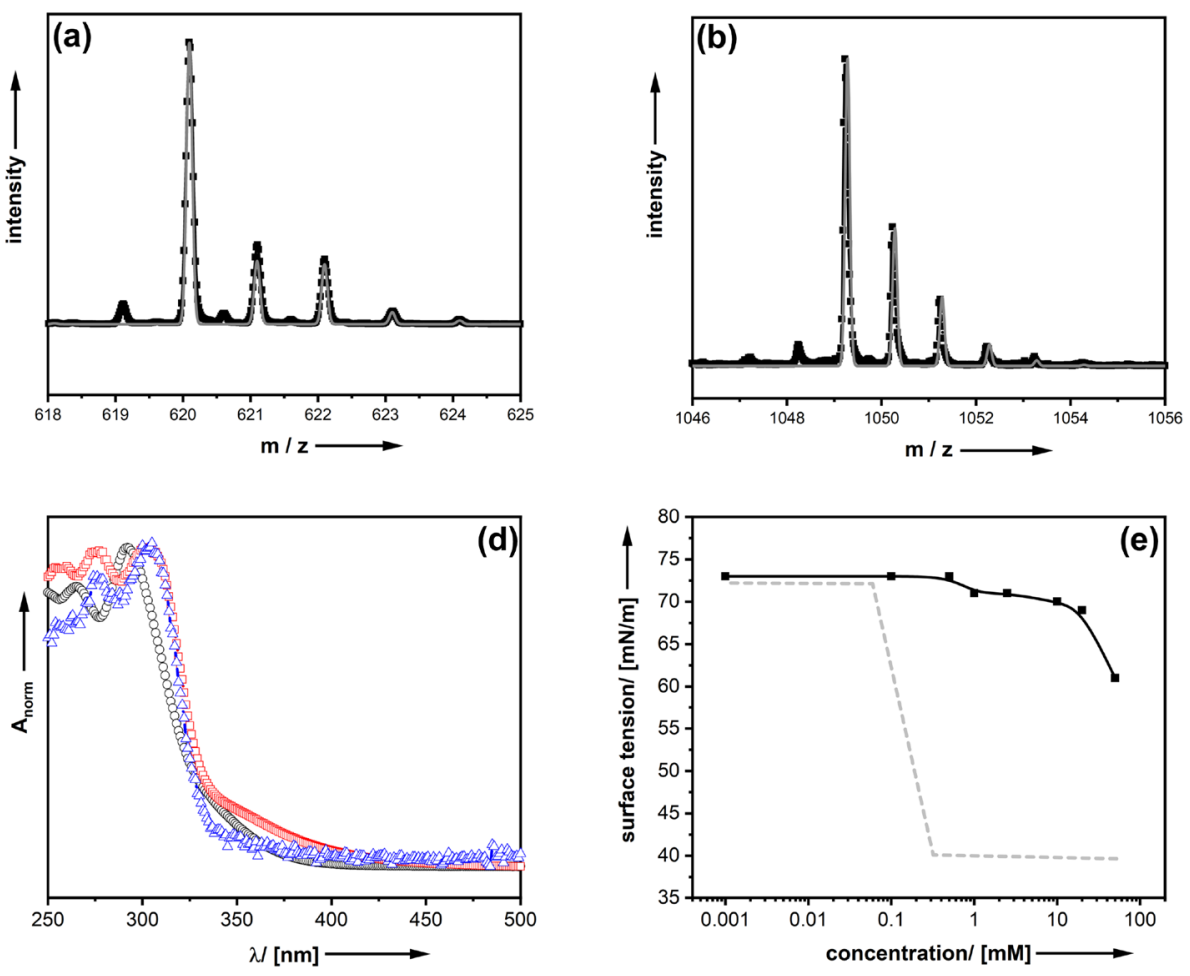

(c)

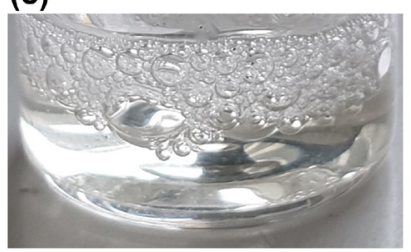

Figure 2. Characterization and hydrolytic stability tests of representative $\mathrm{M}-\mathrm{DO} 3 \mathrm{~A}-\mathrm{C}_{4}-\mathrm{SO}_{3}$ compounds dissolved in aqueous solution at neutral and alkaline $\mathrm{pH}$ values. (a) ESI-MS pattern of Ce-DO3A-C $-\mathrm{SO}_{3}$ (black = measurement; grey = simulation for $\mathrm{M}=\left[\mathrm{Ce}-\mathrm{DO} 3 \mathrm{~A}-\mathrm{C}_{4}-\mathrm{SO}_{3} \mathrm{H}\right] \mathrm{H}^{+}$. (b) ESI-MS pattern of Sc-DO3A$\mathrm{C}_{4}-\mathrm{SO}_{3}$ (black = measurement; grey = simulation for $\mathrm{M}=\left[\mathrm{Sc}-\mathrm{DO} 3 \mathrm{~A}-\mathrm{C}_{4}-\mathrm{SO}_{3}\right]_{2}$. (c) Photographic image of a solution of Ce-DO3A-C $-\mathrm{SO}_{3}$ in water. (d) UV-VIS spectra (absorption normalized) of Ce-DO3A-C $-\mathrm{SO}_{3}$ in water at $\mathrm{pH}=7$ (black circles), $\mathrm{pH}=12$ (red squares) and $\mathrm{pH}=12 ; \mathrm{t}=48 \mathrm{~h}$ (blue triangles). (e) concentration dependent surface tension for $\mathrm{Ce}-\mathrm{DO} 3 \mathrm{~A}-\mathrm{C}_{4}-\mathrm{SO}_{3}$; black = experimental points, grey=idealized behavior for a surfactant as a reference.

confirms a strong coordination of the different Lewis-acidic metal ions. Sc ${ }^{3+}$ was selected, because Kanai et al. have presented a study in 2017 about triflate salts used for peptide bond-cleavage ${ }^{19}$. However, the authors have not used amphiphilic compounds nor demonstrated stability of the catalysts at elevated $\mathrm{pH}$ values in aqueous medium. An advantage of Ce-DO3A- $\mathrm{C}_{4}-\mathrm{SO}_{3}$ is that it is very simple to decide whether treatment of the compound with water induces a release of the metal atom in particular at high $\mathrm{pH}$ values $(\mathrm{pH} 12)$. The addition of hydroxide ions to a solution of free $\mathrm{Ce}^{3+}$ ions induces a rapid formation of a purple precipitate corresponding to a $\mathrm{Ce}$ (III)-oxide-hydroxide phase ${ }^{20,21}$. Visual inspection (Fig. 2c) indicates that there is no precipitate for CeDO3A- $\mathrm{C}_{4}-\mathrm{SO}_{3}$, and the solution still looks clear. Therefore, it seems $\mathrm{Ce}^{3+}$ is sufficiently stabilized against hydrolysis. The same conclusion can be drawn from UV-VIS spectra shown in Fig. 2d. Ce-DO3A-C $-\mathrm{SO}_{3}$ shows good solubility in water, and at neutral $\mathrm{pH}$ one obtains a colourless solution with absorption bands in the UV-region $\left(\lambda_{\max }=295 \mathrm{~nm}\right)$. The absorption pattern does not change at $\mathrm{pH} 12$. There is only a slight red-shift of the bands $\left(\lambda_{\max }=302 \mathrm{~nm}\right)$, which can be explained by an altered ionic strength of the solution. There are no indications for a hydrolytic attack of hydroxide ions even after prolonged times $(\mathrm{pH} \mathrm{12,t}=48 \mathrm{~h})$. The compound is stable in water. Analogous experiments were performed with Sc-DO3A- $\mathrm{C}_{4}-\mathrm{SO}_{3}$ and the same result was obtained.

The conclusion that there is not leaching of the metal ions is in perfect agreement with literature on the quantitative determination of complex formation constants $\mathrm{K}$ of the DOTA ligand with diverse metal cations. $\log (\mathrm{K})$ is typically in the range 15-20 for lanthanides ${ }^{22}$, and can even reach $27 \mathrm{for} \mathrm{Sc}^{3+23}$. This explains, why we have not seen a change in the UV-VIS signals over time and also no precipitation of (oxy-)hydroxides.

A characteristic shape of the concentration-dependent surface tension is expected for a compound with surfactant properties, $i$. e. a steep decrease due to the population of the air-water interface by surfactant molecules, followed by a plateau, when the surface is fully covered and aggregates (e. g. micelles) form in solution. Figure 2e illustrates the behaviour of Ce-DO3A-C $-\mathrm{SO}_{3}$ is rather different, as the surface tension of the aqueous phase remains almost unchanged up to very high concentrations of the compound. Consequently, Ce-DO3A$\mathrm{C}_{4}-\mathrm{SO}_{3}$ is not or only weakly surface-active. Even though all carboxylate groups are coordinated (Fig. 1/(6)), the Ce-DO3A moiety is not hydrophobic enough to complement the short $\mathrm{C}_{4}$ alkyl chain. The same result was obtained for all M-DO3A- $\mathrm{C}_{4}-\mathrm{SO}_{3}$.

Bola M-DO3A- $C_{11}-S H$ compounds. To improve the amphiphilic character, the hydrophobic block of the compounds has to be enlarged. Beyond that, the polarity of the second terminal functionality was adjusted, i. e. a less polar thiol group was chosen, which still provides sufficient solubility in aqueous media. Therefore, for the 
(a)

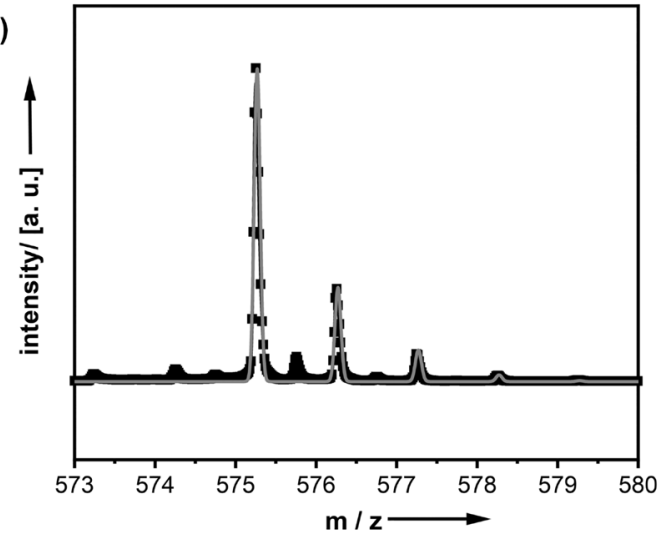

(b)

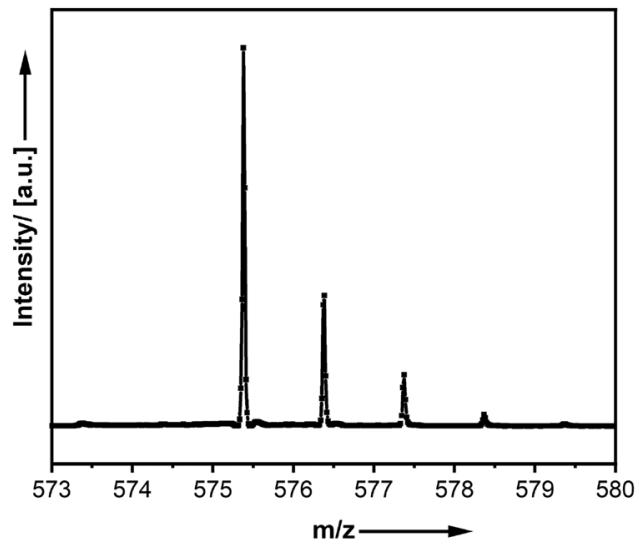

Figure 3. Characterization of Sc-DO3A-C $\mathrm{C}_{11}-\mathrm{SH}$ surfactant synthesized according to Fig. 1b. (a) ESI-MS pattern of Sc-DO3A-C ${ }_{11}-\mathrm{SH}$; black = experimental pattern, grey = pattern simulated for $\mathrm{M}=\left[\mathrm{Sc}-\mathrm{DO} 3 \mathrm{~A}-\mathrm{C}_{11}-\mathrm{SH}\right]$ $\mathrm{H}^{+}$. (b) ESI-MS pattern after $48 \mathrm{~h}$ at $\mathrm{pH} 12$.

introduction of a longer alkyl chain consisting of eleven $-\mathrm{CH}_{2}$ units, a nucleophilic substitution reaction with a thioacetate-terminated $\mathrm{C}_{11}$ alkyl bromide was chosen (Fig. 1b). In a subsequent step, the acetate group can be cleaved affording a thiol group. The characterization of the thioacetate-protected compound (8) is summarized in Fig. SI-4.

The coordination of metal ions was found to be highly favoured under alkaline conditions. The ESI-MS pattern of Sc-DO3A- $\mathrm{C}_{11}-\mathrm{SH}$ is shown in Fig. 3a, proving the successful preparation of the compound. Additional characterization via NMR and ATR-IR can be found in Fig. SI-5. In analogy to the sulfonate-terminated $\mathrm{C}_{4}$ compounds discussed above, hydrolysis is strongly retarded for Sc-DO3A- $\mathrm{C}_{11}-\mathrm{SH}$. Even after days at high $\mathrm{pH}$ values of 12, there is almost no precipitation occurring (see SI-6 in the Supporting Information for further details). Further evidence for the high stability against hydrolysis is provided by ESI-MS analysis after $48 \mathrm{~h}$ at pH 12 (Fig. 3b), indicating that the compound is still present in the solution and has not undergone significant decomposition via hydrolysis.

$\mathrm{M}-\mathrm{DO} 3 \mathrm{~A}-\mathrm{C}_{11}-\mathrm{SH}$ shows significantly improved amphiphilic properties. The findings are discussed for ScDO3A-C ${ }_{11}-\mathrm{SH}$ as a representative case. As first indication for surface activity, strong foaming was observed after shaking an aqueous solution. More importantly, concentration-dependent tensiometry experiments reveals surface-activity (Fig. 4a). The critical aggregation concentration is at $2.5 \mathrm{mM}$, which lies in between that of classical surfactants such as sodium dodecyl sulfate (SDS; $8.2 \mathrm{mM})$ or polyoxyethylene-akyl surfactants $(\approx 0.3 \mathrm{mM})$. Above the $\mathrm{cmc}$, aggregates are formed in solution. According to dynamic light scattering (DLS) measurements (see Fig. 4b), the size of these aggregates is about $150 \mathrm{~nm}$ on average, which strongly suggests the presence of larger aggregates such as vesicles or lamellar structures. As the metal-complex is rather bulky, and our experiments have shown it should be treated as a second head group, it is not surprising that the compound behaves different from classical surfactants. To confirm our hypothesis, transmission electron microscopy (TEM) was used (Fig. 4c). The micrographs show aggregated furled sheets. The size of those particles fits to the DLS results and indicate a tendency of the surfactant to form lamellar structures. As shown in SI-7 in the Supporting Information, multi-layered sheet-like structures can also be found. At higher concentration, surfactants can form lyotropic liquid crystals (LLCs). A polarization microscopy image of such a phase is shown in Fig. $4 \mathrm{~d}$. The birefringence clearly indicates the presence of an optically anisotropic phase. The observed pattern (e. g. occurrence of Maltese (crosses) $)^{24}$ fits to the presence of a lamellar phase.

Catalytic testing. As already mentioned, it is a well-known fact that the coordination by a multi-dentate ligand negatively affects the degree of electrophilicity of a metal ion centre and, hence, also its Lewis acidity. 

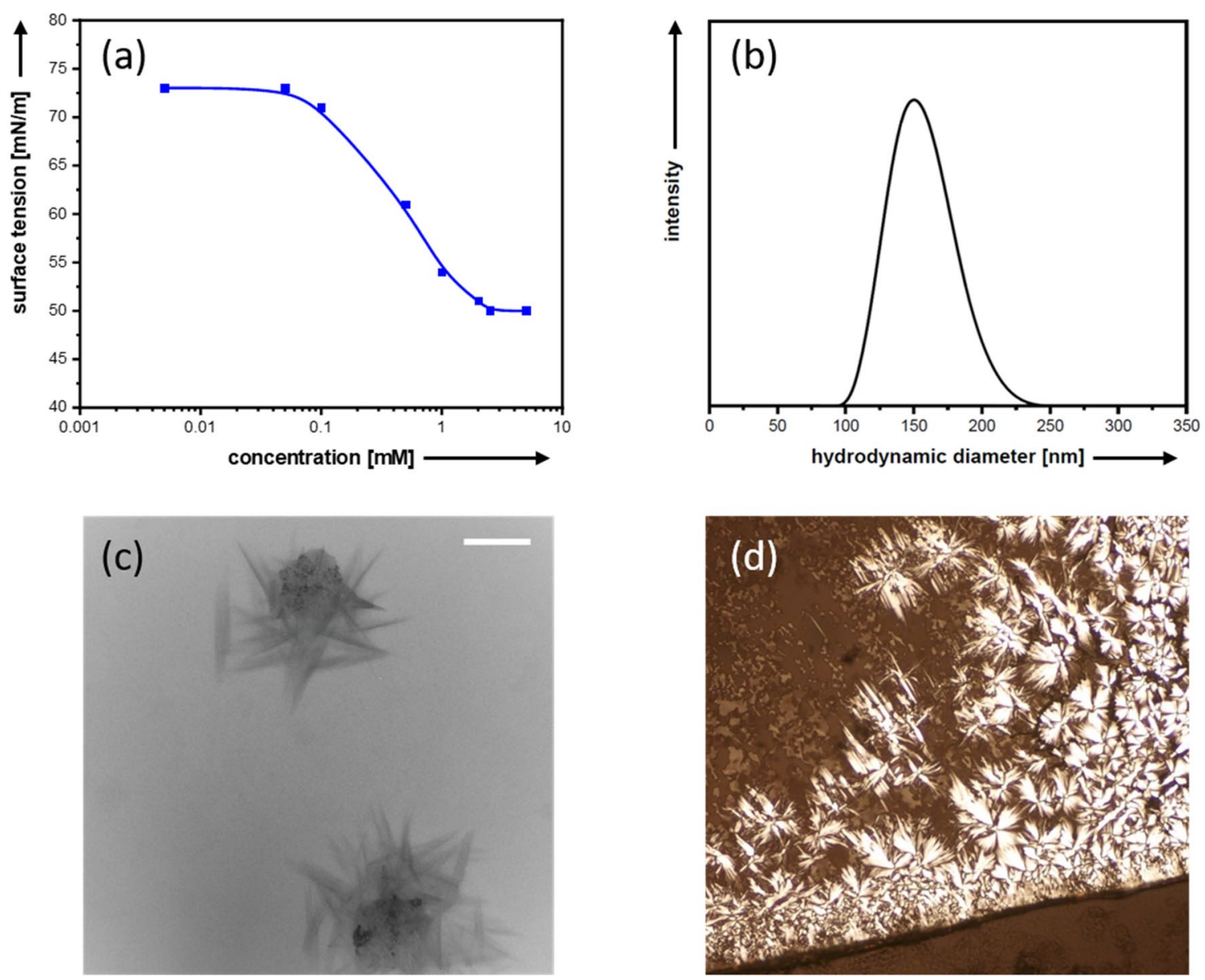

Figure 4. Surfactant-like behavior of Sc-DO3A-C ${ }_{11}-\mathrm{SH}$ in water. Concentration dependent surface tension (a), DLS size distribution function (b) representative TEM image of a dried solution (c; scale bar $=100 \mathrm{~nm}$ ), microscopy image of a high concentration phase under crossed polarizers (d).

The question arises whether there is any catalytic activity remaining despite the coordinative saturation of the metal centre. It is common in literature that Lewis-acid catalysis is investigated by bond formation reactions. For instance, a Mukaiyama aldol-type reaction was already used by Kobayashi et al. as a test for Lewis-acid catalysis $^{25}$. The authors reported high activities for $\mathrm{d}$ - and f-block metal triflates when either a co-solvent, e. g. THF, or a surfactant, e. g. SDS, is added to the aqueous reaction mixture.

Thus, a Mukaiyama aldol reaction and a Michael addition were chosen as representatives for $\mathrm{C}-\mathrm{C}$ bond formation reaction. Notably, despite the strong coordination by hepta-dentate ligands, $\mathrm{Sc}-\mathrm{DO} 3 \mathrm{~A}-\mathrm{C}_{11}-\mathrm{SH}$ shows high catalytic activities comparable to reported Lewis-Acid-surfactant-combined catalysts (LASCs) such as dodecyl sulfate and $\mathrm{Sc}(\mathrm{III})$ or $\mathrm{Yb}(\mathrm{III})$ as counter-ion ${ }^{26}$. The more polar compound Sc-DO3A- $\mathrm{C}_{4}-\mathrm{SO}_{3}$ performs significantly inferior affording no reaction products at all (cf. Table SI-1 in the Supporting Information), which can be explained by its weaker amphiphilic properties compared to Sc-DO3A- $\mathrm{C}_{11}-\mathrm{SH}$. With a conversion of $30 \%$, the latter reaches a similar activity as literature-reported LASCs but is better protected against deactivation by unwanted precipitation at higher $\mathrm{pH}$ values. The broad applicability of $\mathrm{M}-\mathrm{DO} 3 \mathrm{~A}-\mathrm{C}_{11}-\mathrm{SH}$ is confirmed by the results on the Michael addition with indole as hydrophobic, water-immiscible reactant. Again, the surfactant catalyst Sc-DO3A-C $\mathrm{C}_{11}$-SH outperforms the non-amphiphilic Sc-DO3A-C $-\mathrm{SO}_{3}$ with $26 \%$ conversion for only 1 mol- $\%$ of catalyst compared to $11 \%$ conversion for a ten-fold higher catalyst concentration, respectively (cf. Table SI-2 in the Supporting Information). There was no indication of a side-reaction between the thiol group $-\mathrm{SH}$ with any of the electrophilic reagents in the test reactions. Unless strong bases are added to the reaction mixtures, the $-\mathrm{SH}$ group remains stable and no deprotonation occurs.

Bond fission is more relevant for the catalytic attack of organic contaminants. The hydrolytic cleavage of gly-ser dipeptides and the fragmentation of a model protein were selected (Table 1). The conversions were determined in analogy to the procedure reported in reference papers by quantification of ${ }^{1} \mathrm{H}-\mathrm{NMR}$ spectra ${ }^{27,28}$. Reference experiments were performed using the bare organic ligand for ensuring catalytic activity stems from the presence of the metal cation. Furthermore, the integrity of the surfactant-like compounds was verified by analysis (e. g. ESI-MS) after the reaction (see SI-8). Studies were performed with the Sc-containing compounds (6ii) and (9ii), which are both stable against hydrolysis even under strong basic conditions. Because the catalytically active entity is identical, it will be interesting to see, whether the differences in amphiphilic character and polarity again have an effect on the catalytic performance in the cleavage of un-activated amide bonds ${ }^{29}$. The compounds developed in this work show high activity (cf. Table SI-3 in the Supporting Information). Although 


\begin{tabular}{|c|c|c|c|c|}
\hline Cleavage agent & $\begin{array}{l}\text { Molar ratio cleavage agent to } \\
\text { reactants }\end{array}$ & Reaction & Reaction conditions & Conversion \\
\hline This work (6ii) & 1 & Dipeptide cleavage (gly-ser) & $24 \mathrm{~h}, 70^{\circ} \mathrm{C}, \mathrm{pH} 7.0$ & $13 \%$ \\
\hline This work (9ii) & 1 & Dipeptide cleavage (gly-ser) & $24 \mathrm{~h}, 70^{\circ} \mathrm{C}, \mathrm{pH} 7.0$ & $32 \%$ \\
\hline dimeric $\mathrm{Zr}^{(\mathrm{IV})}-\mathrm{POM}^{30}$ & 1 & Dipeptide cleavage (gly-ser) & $24 \mathrm{~h}, 60^{\circ} \mathrm{C}, \mathrm{pD} 5.4(\mathrm{pH} \sim 5.0)$ & $\sim 35 \%$ \\
\hline This work (6ii) & $\sim 1000$ & BSA cleavage & $60^{\circ} \mathrm{C}, \mathrm{pH} 6.0$ & $100 \%$ after $16 \mathrm{~h}$ \\
\hline This work (9ii) & $\sim 1000$ & BSA cleavage & $60^{\circ} \mathrm{C}, \mathrm{pH} 6.0$ & $100 \%$ after $16 \mathrm{~h}$ \\
\hline 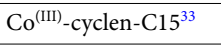 & $\sim 67$ & BSA cleavage & $50^{\circ} \mathrm{C}, \mathrm{pH} 9.0$ & $100 \%$ after $16 \mathrm{~h}$ \\
\hline $\mathrm{Cu}^{(\mathrm{II})}$-cyclen-C15 ${ }^{33}$ & $\sim 67$ & BSA cleavage & $50^{\circ} \mathrm{C}, \mathrm{pH} 9.0$ & $100 \%$ after $39 \mathrm{~h}$ \\
\hline $\mathrm{Cu}^{(\mathrm{II})}-\mathrm{cyclen}^{33}$ & $\sim 20,000$ & BSA cleavage & $50^{\circ} \mathrm{C}, \mathrm{pH} 9.0$ & $\sim 0 \%$ after $48 \mathrm{~h}$ \\
\hline
\end{tabular}

Table 1. Overview over the obtained conversions for peptide bond fission reactions and comparison to bestperforming systems in literature.

the dipeptide is polar and well soluble in water, the amphiphilic character of the catalysts is of importance. The amphiphilic Sc-DO3A-C $\mathrm{C}_{11}$-SH performs better and is 2.5-times more active, affording conversion degrees of $32 \%$. Remarkably, to the best of our knowledge, the compound ranges among the top performing Lewis-acidic catalysts stated in literature. Ly et $\mathrm{al}^{30}$. achieved a yield of about $35 \%$ of cleaved amino acids glycine and serine using an equimolar amount of catalyst (a dimeric Keggin-type polyoxometalate (POM) containing $\mathrm{Zr}(\mathrm{IV})$ ions as active centres), but at acidic conditions, which is known to significantly accelerate the kinetics of a hydrolytic amide bond cleavage ${ }^{31}$. Besides the cleaved amino acids, a minor amount of the cyclic compound c-(gly-ser) was reported by Ly et al. Herein, the amount of the latter was more than four times higher compared to their results. From their investigations, it can be assumed that the hydrolytic cleavage of other dipeptides, e. g. gly-gly, or cyclic peptides will also be feasible using the Lewis-acidic metal-organic complexes developed in this work.

Because of its superior performance, we have focussed on Sc-DO3A- $\mathrm{C}_{11}-\mathrm{SH}$ for our final tests. A protein is a much more realistic compound for an organic contaminant present in practical fields of application of Lewis acidic surfactants. Thus, SDS-PAGE was performed using BSA (bovine serum albumin) as a protein (Fig. 5). SDS-PAGE stands for sodium dodecyl sulfate polyacrylamide gel electrophoresis ${ }^{29}$, and it is a well-established method for the analysis of polypeptides and its fragments. One can see, Sc-DO3A- $\mathrm{C}_{11}-\mathrm{SH}$ is active. At neutral $\mathrm{pH}$ and at room temperature, the stability of a peptide bond is extraordinarily high with a reported half-life of up to 600 years $^{32}$. Lewis-acidic compounds can significantly accelerate the cleavage reaction kinetics. Indeed, quantitative fragmentation of BSA has taken place after $16 \mathrm{~h}$ of treatment in water at $\mathrm{pH} 6$ and a concentration of the cleavage agent of $2.0 \mathrm{mM}$ (1000-fold molar excess). Perera-Bobusch et al. ${ }^{33}$ reported excellent activities for $\mathrm{Co}^{3+}$ coordinated by a cyclen moiety to which one $\mathrm{C}_{16}$ alkyl chain was covalently attached. After $16 \mathrm{~h}$ of incubation, a 67 -fold molar excess of Lewis acidic cleavage agent respective to BSA was necessary for quantitative cleavage. However, the cleavage reactions were performed at $\mathrm{pH}$ 9. When the $\mathrm{pH}$ was set to 7.4, significant decreases in cleavage activities were admitted by the authors. Disadvantageously, $\mathrm{Co}^{3+}$ species are highly toxic and could easily leach into the surrounding solution, as the complex formation constant is rather low for monoalkylated cyclen ligands. For a similar system comprised of non-toxic $\mathrm{Cu}^{2+}$ ions as active species for bond cleavage, inferior cleavage properties were observed. The high proteolytic activity of Sc-DO3A- $\mathrm{C}_{11}-\mathrm{SH}$ in this study is expected to be a consequence of the long hydrophobic alkyl chain that favours interaction with the hydrophobic pockets in the protein. Besides high activity, sufficient stability of the compound in the presence of the protein at elevated temperature is manifested since there is no formation of a precipitate or gel during the cleavage reaction. Moreover, a pre-treatment in alkaline solution prior to the cleavage reactions had no adverse effect on the cleavage activities of the Lewis-acidic compounds due to their sufficient protection against hydrolysis by the strongly coordinating DO3A ligand (see 4.2.2 in the Supporting Information).

\section{Conclusion}

It occurs very often that the character of dirt is at least partially hydrophobic. Sometimes the skills of conventional surfactants to solubilize such hydrophobic contaminants are not sufficient. Thus, our aim was the exploitation of surfactants, which contain a catalytically active constituent with strong Lewis-acidity. A ligand containing a cyclen derivative modified by three acetic acid groups (DO3A) in a terminal position attached to one alkyl chain was prepared. An additional group, either $-\mathrm{SO}_{3} \mathrm{H}$ or $-\mathrm{SH}$, responsible for higher solubility in water was introduced at the other terminus of the aliphatic alkyl chain. After coordination to different metal ions like $\mathrm{Zn}^{2+}$, $\mathrm{Ce}^{3+}, \mathrm{Yb}^{3+}$ and, most importantly, $\mathrm{Sc}^{3+}$, depending on the length of the hydrocarbon chain, a non-amphiphilic and a surfactant-like compound were obtained. Both compounds were highly stable in water and survived the treatment at $\mathrm{pH} 12$ for more than two days. It was demonstrated that the metal-DO3A complex is still catalytically active regarding bond-formation and bond-cleavage reactions. Despite the strong electron donating properties of the macrocyclic ligand being essential for hydrolytic stability over a broad range of $\mathrm{pH}$ values, the metal ion still remains catalytically active in different Lewis-acid catalyzed bond formation as well as cleavage reactions. Hence, the systems presented in this work address the well-known trade-off between high catalytic activity and stability. Overall, the performance of the surfactant catalyst is better, and in case one of the substrates is hydrophobic, the amphiphilic character proved to be vital. Thus, in future studies it could be worth to change amphiphilicity by the adjustment of the hydrocarbon chain length. 
ref.
marker
$(2 \mu \mathrm{M}$
BSA)

\section{$1.0 \mathrm{mM} \quad 2.0 \mathrm{mM}$}

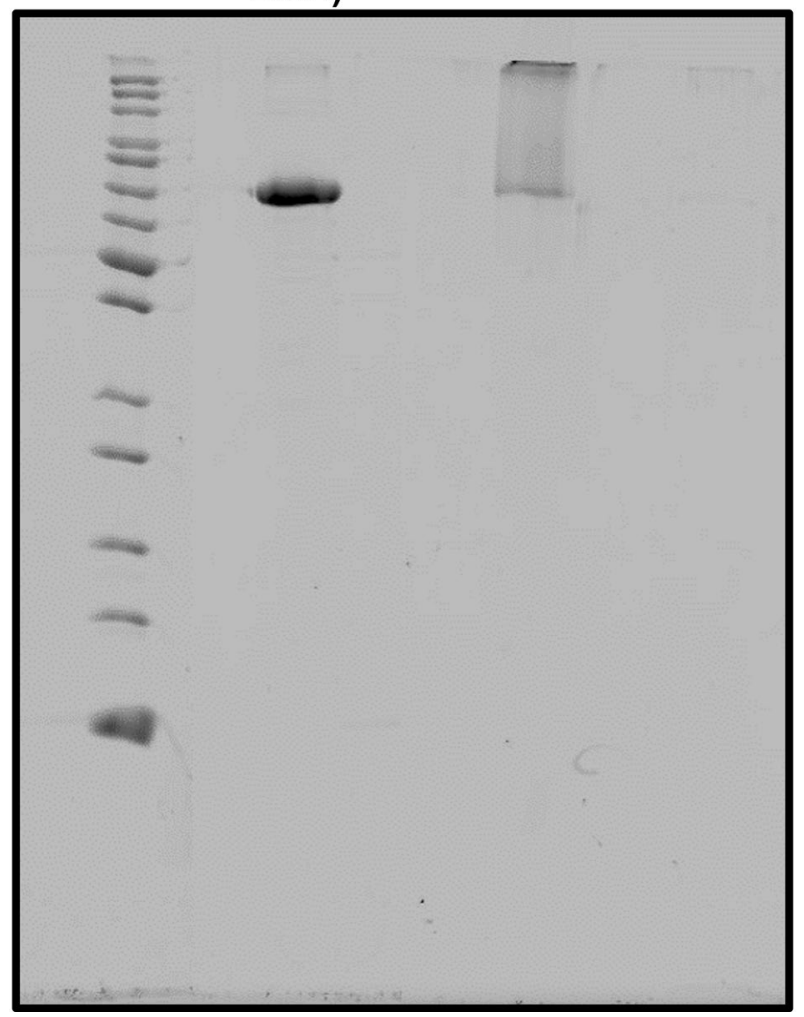

Figure 5. SDS-PAGE of the hydrolytic cleavage of BSA at $\mathrm{pH} 6$ and $60^{\circ} \mathrm{C}$ for $16 \mathrm{~h}$ using Sc-DO3A-C $11^{-} \mathrm{SH}$ (9ii) as a surfactant-cleavage agent. A reference experiment without cleavage agent using a concentration of $2 \mu \mathrm{M}$ BSA is shown next to the marker.

\section{Methods}

All chemicals were used as received, unless otherwise stated. N,N-dimethylacetamide (DMA; 99\%), acetic acid (100\%), cyclen (95\%), glycyl- $L$-serine (gly-ser; $97 \%)$ and anhydrous cerium(III)-chloride $\left(\mathrm{CeCl}_{3} ; 99.9 \%\right)$ were purchased from $a b c r$. Anhydrous scandium(III)-chloride $\left(\mathrm{ScCl}_{3} ; 99.9 \%\right)$, anhydrous ytterbium(III)-chloride $\left(\mathrm{YbCl}_{3} ; 99.9 \%\right)$, tert-butyl bromoacetate $(98 \%)$, trifluoroacetic acid (TFA; 99.9\%), benzaldehyde (>99\%), sodium acetate (>99\%), S-(11-bromoundecyl) thioacetate (>90\%), indole (>99\%), methyl vinyl ketone (99\%), 1-(trimethylsiloxy)cyclohexene (99\%) were purchased from Sigma-Aldrich (Merck). BSA protein (in ultrapure 0.9\% saline solution with $0.05 \%$ sodium azide) was purchased from Thermo Fisher Scientific). Anhydrous zinc(II)chloride $\left(\mathrm{ZnCl}_{2} ;>98 \%\right)$ was purchased from ACROS Organics. MilliQ- $\mathrm{H}_{2} \mathrm{O}$ was generated using a MilliQ-system. Methanol $(\mathrm{MeOH})$, ethanol (EtOH), tetrahydrofuran (THF), chloroform $\left(\mathrm{CHCl}_{3}\right)$ and dichloromethane (DCM) were used in $p$. $a$. grade.

Synthesis. 1,4,7-tris(tert-butoxycarbonylmethyl)-1,4,7,10-tetraazacyclodode-cane free base (DO3A- ${ }^{t} \mathrm{Bu}$ (3)). As first step, commercially available cyclen (1) was selectively tris-alkylated with tert-butyl bromoacetate to yield the hydrobromide salt of 1,4,7-tris(tert-butoxycarbonylmethyl)-1,4,7,10-tetraazacyclododecane (DO3A$\left.{ }^{t} \mathrm{Bu} \cdot \mathrm{HBr}(2)\right)$. In a second step, the corresponding free base was afforded in excellent yields. The synthesis method of Jagadish et al. ${ }^{18}$ was reproduced leading to high yields of the tris-alkylated compound (2) owing to kinetic control during the nucleophilic substitution reaction at low temperatures. In brief, $5.00 \mathrm{~g}$ cyclen $(29 \mathrm{mmol}$, 1.0 eq.) and 7.87 g sodium acetate ( $96 \mathrm{mmol}, 3.3$ eq.) were dissolved in $60 \mathrm{~mL} \mathrm{~N}, N$-dimethylacetamide (DMA) under vigorous stirring. $18.7 \mathrm{~g}$ tert-butyl bromoacetate $(14.1 \mathrm{~mL}, 96 \mathrm{mmol}, 3.3 \mathrm{eq}$.) in $20 \mathrm{~mL}$ DMA were added dropwise to the suspension at $-20^{\circ} \mathrm{C}$. After vigorous stirring for $24 \mathrm{~h}$, the reaction mixture was poured into $300 \mathrm{~mL}$ deionized water and $15 \mathrm{~g} \mathrm{KHCO}_{3}$ were added. The precipitate was collected by filtration, redissolved in $250 \mathrm{~mL} \mathrm{CHCl}_{3}$, washed with $100 \mathrm{~mL}$ deionized water, dried $\left(\mathrm{MgSO}_{4}\right)$ and concentrated to $25 \mathrm{~mL}$. For the crystallization of (2), $250 \mathrm{~mL} \mathrm{Et}_{2} \mathrm{O}$ were added. After filtration, washing with $\mathrm{Et}_{2} \mathrm{O}$ and drying in vacuo, $5.00 \mathrm{~g}$ of (2) ( $8.4 \mathrm{mmol}, 1.0$ eq.) were dissolved in $250 \mathrm{~mL}$ deionized water at $80^{\circ} \mathrm{C} .9 .4 \mathrm{~mL} 10 \%$ aq. $\mathrm{KOH}(16.8 \mathrm{mmol}, 2.0$ eq. $)$ were added at $40^{\circ} \mathrm{C}$ and the reaction mixture was stirred for $30 \mathrm{~min}$. After extraction with hexanes $(3 \times 100 \mathrm{~mL})$, the organic phase was washed with deionized water $(3 \times 100 \mathrm{~mL})$. The free base $(3)$ was yielded as a colorless, viscous oil after a drying step $\left(\mathrm{MgSO}_{4}\right)$, filtration and concentration under reduced pressure. Overall yield of 
DO3A- ${ }^{t}$ Bu (3): $63 \% .{ }^{1} \mathrm{H}-\mathrm{NMR}\left(400 \mathrm{MHz}, \mathrm{CDCl}_{3}\right)$ : $\delta 1.44$ (br s, $\left.9 \mathrm{H}\right), 1.45$ (br s, $\left.18 \mathrm{H}\right), 2.55-2.89(\mathrm{~m}, 16 \mathrm{H}), 3.31$ (s, $2 \mathrm{H}), 3.33$ (s, $4 \mathrm{H})$. ESI-MS (+): $515.376\left([\mathrm{M}+\mathrm{H}]^{+}\right.$, calcd. 515.380).

4-(4,7,10-tris(2-(tert-butoxy)-2-oxoethyl)-1,4,7,10-tetraazacyclodo-decan-1-yl)butane-1-sulfonate (DO3A$\left.{ }^{t} \mathrm{Bu}_{-} \mathrm{C}_{4}-\mathrm{SO}_{3}(4)\right)$. In a typical synthesis, $1.60 \mathrm{~g} \mathrm{(3)}$ (3.1 mmol; 1.0 eq.) were dissolved in $20 \mathrm{~mL}$ anhydrous THF under nitrogen gas atmosphere. $0.45 \mathrm{~g}$ freshly distilled 1,4-butane sultone ( $3.3 \mathrm{mmol} ; 1.05 \mathrm{eq}$.) were dissolved in $20 \mathrm{~mL}$ anhydrous THF and added to the boiling reaction mixture over a period of $20 \mathrm{~min}$. After refluxing for $48 \mathrm{~h}$ at $60^{\circ} \mathrm{C}$, the solvent was removed in vacuo. A recrystallization step using a mixture of $1 / 30 \mathrm{MeOH} / \mathrm{Et}_{2} \mathrm{O}$ was performed. The formed colorless precipitate was collected using a filtration step and washed with $\mathrm{Et}_{2} \mathrm{O}(3 \times 20 \mathrm{~mL})$. After drying in vacuo, (4) was afforded as a colorless solid. Yield of DO3A- ${ }^{t} \mathrm{Bu}^{-} \mathrm{C}_{4}-\mathrm{SO}_{3}(4)$ : $76 \%$. Characterization was performed via NMR spectroscopy $\left({ }^{1} \mathrm{H},{ }^{13} \mathrm{C},{ }^{15} \mathrm{~N}\right.$, COSY \& HSQC), via ESI-MS and ATR-IR spectroscopy.

2,2',2' -(10-(4-sulfobutyl)-1,4,7,10-tetraazacyclododecane-1,4,7-tri-yl)tri-acetic acid (TFA salt) (DO3A$\mathrm{C}_{4}-\mathrm{SO}_{3}(5)$ ). In a typical TFA deprotection, $1.53 \mathrm{~g}(4)$ were dissolved in $20 \mathrm{~mL}$ TFA under $\mathrm{N}_{2}$. The solution was stirred vigorously for $24 \mathrm{~h}$ at $25^{\circ} \mathrm{C}$. Remaining TFA was removed in vacuo and $2 \mathrm{~mL} \mathrm{MeOH} p$. a. were added to redissolve the obtained colorless solid residue. At $5^{\circ} \mathrm{C}, 50 \mathrm{~mL} \mathrm{Et}{ }_{2} \mathrm{O}$ were added slowly under stirring. The reaction mixture was stirred for further $2 \mathrm{~h}$ without cooling. A filtration step was performed to collect the colorless solid precipitate, which was dried in vacuo. Yield of DO3A- $\mathrm{C}_{4}-\mathrm{SO}_{3}(5)$ : Quantitative. Characterization of the compound was performed via ${ }^{1} \mathrm{H}$ and ${ }^{13} \mathrm{C}-\mathrm{NMR}$ spectroscopy, via ESI-MS and ATR-IR spectroscopy. ${ }^{1} \mathrm{H}-\mathrm{NMR}$ $\left(400 \mathrm{MHz}, \mathrm{D}_{2} \mathrm{O}\right): \delta 1.76-2.02\left(\mathrm{~m}, 4 \mathrm{H}, \mathrm{H}_{\mathrm{f}}\right), 2.93-3.02\left(\mathrm{t}, 2 \mathrm{H}, \mathrm{H}_{\mathrm{e}}\right), 3.02-3.24\left(\mathrm{~m}, 8 \mathrm{H}, \mathrm{H}_{\mathrm{d}}\right), 3.29-3.38(\mathrm{t}, 2 \mathrm{H}$, $\left.\mathrm{H}_{\mathrm{c}}\right), 3.40-3.70\left(\mathrm{~m}, 12 \mathrm{H}, \mathrm{H}_{\mathrm{b}}\right), 4.03-4.15\left(\mathrm{~s}, 2 \mathrm{H}, \mathrm{H}_{\mathrm{a}}\right)$. ESI-MS (+): $483.214\left([\mathrm{M}+\mathrm{H}]^{+}\right.$, calcd. 483.212$) ; 505.194$ $\left([\mathrm{M}+\mathrm{Na}]^{+}\right.$, calcd. 505.194).

Complexation of various transition metal and lanthanide ions (M-DO3A- $\left.\mathrm{C}_{4}-\mathrm{SO}_{3}(6)\right)$. The complexation of different metal ions using $7 \mathrm{M}$ ammonia in methanol was achieved under strictly anhydrous reaction conditions and inert gas atmosphere $\left(\mathrm{N}_{2}\right)$ to prevent precipitation of insoluble metal hydroxides or oxides. In a typical syn-

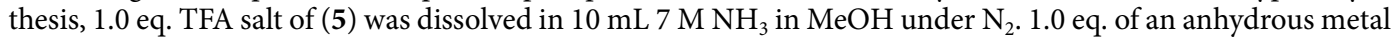
chloride salt $\left(\mathrm{MCl}_{\mathrm{x}}\right)$ dissolved in $5 \mathrm{~mL}$ dry $\mathrm{MeOH}$ was added dropwise $\left(\mathrm{N}_{2}\right)$. Depending on the nature of the metal ion, a color change occurred during the addition, e.g. to purple in the case of $\mathrm{Ce}$ (III) and some colorless precipitate was formed. The reaction mixture was heated to reflux for $48 \mathrm{~h}\left(\mathrm{~N}_{2}\right)$. After removal of the solvent in vacuo. $20 \mathrm{~mL}$ MilliQ- $\mathrm{H}_{2} \mathrm{O}$ were added, ultrasound was applied for $5 \mathrm{~min}$ and a syringe-filtration step was performed to remove insoluble residues. The solvent was removed via freeze-drying. In the case of Ce-DO3A- $\mathrm{C}_{4}-\mathrm{SO}_{3}(6 \mathrm{i}) \mathrm{a}$ slightly yellow solid, for Sc-DO3A-C $-\mathrm{SO}_{3}$ (6ii), $\mathrm{Zn}-\mathrm{DO} 3 \mathrm{~A}-\mathrm{C}_{4}-\mathrm{SO}_{3}$ (6iii) and $\mathrm{Yb}-\mathrm{DO} 3 \mathrm{~A}-\mathrm{C}_{4}-\mathrm{SO}_{3}$ (6iv) colorless solids were afforded. Yields for the different metal-organic complexes (6): Quantitative. Characterization of the metal complexes was performed via ${ }^{1} \mathrm{H}$ and ${ }^{13} \mathrm{C}$-NMR spectroscopy for the diamagnetic complexes $\mathrm{Zn}-\mathrm{DO} 3 \mathrm{~A}-$ $\mathrm{C}_{4}-\mathrm{SO}_{3}$ and $\mathrm{Sc}-\mathrm{DO} 3 \mathrm{~A}-\mathrm{C}_{4}-\mathrm{SO}_{3}$, besides ESI-MS and ATR-IR spectroscopy. For the paramagnetic complexes CeDO3A-C $-\mathrm{SO}_{3}$ and $\mathrm{Yb}-\mathrm{DO} 3 \mathrm{~A}-\mathrm{C}_{4}-\mathrm{SO}_{3} \mathrm{ESI}-\mathrm{MS}$ and ATR-IR spectroscopy were performed. For all complexes, IR spectroscopy indicated the presence of ammonium counter-ions.

Tri-tert-butyl 2,2',2'"-[10-(11-(acetylthio)undecyl)-1,4,7,10-tetraaza-cyclododecane-1,4,7-triyl] triacetate (DO3A- ${ }^{t} \mathrm{Bu}-\mathrm{C}_{11}$-SAc (7)). $0.50 \mathrm{~g}$ DO3A- ${ }^{t} \mathbf{B u}(3)$ (1.00 mmol; 1.0 eq.) were dissolved in $20 \mathrm{~mL} \mathrm{CHCl}_{3}$ under nitrogen gas atmosphere. $0.12 \mathrm{~g}$ triethylamine $\left(1.20 \mathrm{mmol} ; 1.2 \mathrm{eq}\right.$.) were added dropwise under stirring and $\mathrm{N}_{2}$. The solution was heated to reflux and $0.33 \mathrm{~g} S$-(11-bromoundecyl) thioacetate $(1.07 \mathrm{mmol}$; $1.1 \mathrm{eq}$.) dissolved in $10 \mathrm{~mL} \mathrm{CHCl}_{3}$ were added dropwise. The reaction mixture was refluxed for further $24 \mathrm{~h}\left(\mathrm{~N}_{2}\right)$. The organic phase was extracted with $20 \mathrm{~mL}$ distilled water to remove triethylamine salts and then dried $\left(\mathrm{MgSO}_{4}\right)$. The solvent was removed and the obtained pale yellow solid (7) was finally dried in vacuo. Yield of DO3A-t $\mathbf{B u}-\mathbf{C}_{\mathbf{1 1}}-\mathbf{S A c}$ (7): Quantitative. ${ }^{1} \mathrm{H}-\mathrm{NMR}\left(400 \mathrm{MHz}, \mathrm{CDCl}_{3}\right): \delta 1.23-1.37$ (br m, $\left.18 \mathrm{H}\right), 1.43-1.47$ (br s, $\left.27 \mathrm{H}\right), 2.31(\mathrm{~s}, 3 \mathrm{H})$, 2.50-3.23 (br m, $18 \mathrm{H}), 3.26-3.46$ (br m, 8 H). ESI-MS (+): $743.530\left([\mathrm{M}+\mathrm{H}]^{+}\right.$, calcd. 743.535).

2,2',2'-(10-(11-(acetylthio)undecyl)-1,4,7,10-tetraaza-cyclododecane-1,4,7-triyl)triacetic acid (DO3A-C ${ }_{11}{ }^{-}$ $\mathrm{SAc}(8))$. In a typical deprotection procedure, $0.63 \mathrm{~g} \mathrm{DO} 3 \mathrm{~A}-{ }^{t} \mathrm{Bu}-\mathrm{C} 11-\mathrm{SAc}$ (7) $(0.85 \mathrm{mmol})$ were dissolved in $10 \mathrm{~mL} \mathrm{DCM}$ and $20 \mathrm{~mL}$ TFA were added at $25^{\circ} \mathrm{C}$ under nitrogen gas atmosphere. The reaction mixture was stirred for $2 \mathrm{~d}$ at $25^{\circ} \mathrm{C}\left(\mathrm{N}_{2}\right)$. A yellow-orange solution was obtained. The solvents were removed under reduced pressure. $1.0 \mathrm{~g}$ of a yellow oil was afforded, which was purified via recrystallization. The yellow oil was dissolved in $2 \mathrm{~mL} \mathrm{MeOH}$ and $50 \mathrm{~mL} \mathrm{Et}_{2} \mathrm{O}$ were added slowly at $5^{\circ} \mathrm{C}$. A yellow-brownish precipitate formed and the reaction mixture was stirred for further $4 \mathrm{~h}$ at $25^{\circ} \mathrm{C}$. The solvents were decanted and the remaining solid residue was washed several times with $\mathrm{Et}_{2} \mathrm{O}$. DO3A- $\mathrm{C}_{11}-\mathrm{SAc}(8)$ was afforded after a drying step in vacuo as yellow solid. Yield of DO3A-C ${ }_{11}$-SAc (8): 82\%. ${ }^{1} \mathrm{H}-\mathrm{NMR}\left(400 \mathrm{MHz}, \mathrm{D}_{2} \mathrm{O}\right): \delta 1.25-1.45$ (br m, $\left.14 \mathrm{H}\right), 1.52-1.66(\mathrm{q}, 2 \mathrm{H}), 1.68-1.85$ $(\mathrm{m}, 2 \mathrm{H}), 2.35-2.43(\mathrm{~s}, 3 \mathrm{H}), 2.87-2.95(\mathrm{t}, 2 \mathrm{H}), 3.03-3.31(\mathrm{~m}, 12 \mathrm{H}), 3.39-3.67(\mathrm{~m}, 10 \mathrm{H}), 3.91(\mathrm{~s}, 2 \mathrm{H})$. ESI-MS (+): $575.380\left([\mathrm{M}+\mathrm{H}]^{+}\right.$, calcd. 575.347).

M-DO3A- $C_{11}-S H(9)$. In a typical synthesis, $0.34 \mathrm{~g}$ TFA salt of DO3A-C $\mathbf{C l}_{1}-\mathrm{SAc}(\mathbf{8})(0.5 \mathrm{mmol} ; 1.0$ eq.) were dissolved in $10 \mathrm{~mL} 7 \mathrm{M}$ ammonia in $\mathrm{MeOH}$ under nitrogen gas atmosphere and strictly anhydrous conditions. The reaction mixture was stirred for $15 \mathrm{~min}\left(\mathrm{~N}_{2}\right)$. Then, $78 \mathrm{mg}$ anhydrous $\mathrm{ScCl}_{3}(0.52 \mathrm{mmol} ; 1.05$ eq. $)$ dissolved in $5 \mathrm{~mL}$ dry $\mathrm{MeOH}$ were added dropwise $\left(\mathrm{N}_{2}\right)$. The reaction mixture was heated to reflux for $3 \mathrm{~d}$ at $75^{\circ} \mathrm{C}$ $\left(\mathrm{N}_{2}\right)$. A syringe-filtration step was used to remove insoluble residues from the obtained turbid reaction mixture. The solvent was removed in vacuo and $0.29 \mathrm{~g}$ of a colorless solid could be afforded after recrystallization from $1 / 50 \mathrm{MeOH} / \mathrm{Et}_{2} \mathrm{O}$ at $5{ }^{\circ} \mathrm{C}$. Yield of (9ii): Quantitative. The compound Sc-DO3A-C $\mathbf{1 1}_{1}-\mathbf{S H}$ (9ii) was characterized via ${ }^{1} \mathrm{H}$ - and ${ }^{13} \mathrm{C}$-NMR spectroscopy, DOSY and HSQC experiments in MeOD- $\mathrm{d}_{4}$. ESI-MS further revealed a successful complexation of $\mathrm{Sc}^{3+}$ and deprotection of the thioacetate moiety. This was also investigated via ATR-IR spectroscopy. Amphiphilic properties were examined via pendant drop tensiometry and the capillary rise method. In another synthesis approach, the complexation of $\mathrm{Ce}(\mathrm{III})$ via anhydrous $\mathrm{CeCl}_{3}$ could be accomplished. $77 \mathrm{mg}$ DO3A-C $\mathbf{1 1}_{1}$-SAc (8) (0.13 mmol; 1.0 eq.) were dissolved in $10 \mathrm{~mL} 7 \mathrm{M}$ ammonia in $\mathrm{MeOH}$ under 
$\mathrm{N}_{2}$ and strictly anhydrous conditions. The solution was stirred for $10 \mathrm{~min}$ at $25^{\circ} \mathrm{C}$. Afterwards, $38 \mathrm{mg}$ anhydrous $\mathrm{CeCl}_{3}\left(0.14 \mathrm{mmol}\right.$; 1.1 eq.) dissolved in $2 \mathrm{~mL}$ dry $\mathrm{MeOH}$ were added dropwise $\left(\mathrm{N}_{2}\right)$. The reaction mixture was heated to reflux for $2 \mathrm{~d}\left(\mathrm{~N}_{2}\right)$. A weakly turbid solution was afforded. Yield of (9i): Quantitative. Compound CeDO3A-C $11-$ SH (9i) was characterized via ESI-MS.

Catalytic test reactions.. $\quad$ Mukaiyama aldol reaction. $\quad 30 \mathrm{mg}$ benzaldehyde ( $0.3 \mathrm{mmol}$; 1.0 eq.) were suspended in $10.0 \mathrm{~g}$ distilled water and a certain amount of catalyst $(10 \mathrm{~mol}-\%)$ was added to the turbid mixture. Then, $53 \mathrm{mg}$ 1-(trimethylsiloxy) cyclohexene $(0.31 \mathrm{mmol}$; $1.1 \mathrm{eq}$.) were added. The reaction mixture was stirred for $20 \mathrm{~h}$ at $25{ }^{\circ} \mathrm{C}$. The organic solvent was removed under reduced pressure and $5.0 \mathrm{~mL}$ distilled water were added. The aqueous phase was extracted with $20 \mathrm{~mL} \mathrm{DCM}$ and after removal of the organic solvent in vacuo, the crude reaction product was dried in vacuo. Characterization of the obtained colorless viscous liquid was performed via ${ }^{1} \mathrm{H}$-NMR spectroscopy in $\mathrm{CDCl}_{3}$. For the calculation of the respective yields of 2-[hydroxy(phenyl) methyl] cyclohexanone, residual signals of benzaldehyde were quantified and subtracted to calculate the yield of the desired aldol reaction product.

Michael addition. $117 \mathrm{mg}$ indole $(1.0 \mathrm{mmol} ; 1.0$ eq.) were suspended in $2.0 \mathrm{~g}$ distilled water. A certain amount of catalyst ( $10 \mathrm{~mol}-\%)$ was added to the suspension. After $5 \mathrm{~min}$ in an ultrasonic bath, $70 \mathrm{mg}$ methyl vinyl ketone ( $1.0 \mathrm{mmol} ; 1.0 \mathrm{eq}$.) were added at $25^{\circ} \mathrm{C}$. After vigorous stirring for $24 \mathrm{~h}$ at $25^{\circ} \mathrm{C}, 2.0 \mathrm{~g}$ distilled water were added to the reaction mixture which was subsequently extracted using $10 \mathrm{~mL}$ ethyl acetate. The organic phase was dried $\left(\mathrm{MgSO}_{4}\right)$ and the solvent was removed under reduced pressure. After drying, the obtained products were analyzed via ${ }^{1} \mathrm{H}-\mathrm{NMR}$ spectroscopy in $\mathrm{dmso}^{-\mathrm{d}_{6}}$. In the case of Sc-DO3A-C $\mathrm{C}_{11} \mathrm{SH}$ (9ii), $117 \mathrm{mg}$ indole (1.0 mmol; 1.0 eq.) were suspended in $4.0 \mathrm{~g}$ distilled water and $5.7 \mathrm{mg}$ catalyst $(0.01 \mathrm{mmol} ; 1 \mathrm{~mol}-\%)$ were dissolved in the turbid mixture. A characteristically smelling yellow oil could be yielded that was further characterized via ${ }^{1} \mathrm{H}$ NMR spectroscopy in dmso- $\mathrm{d}_{6}$.

Hydrolytic cleavage of gly-ser dipeptides. To assess the catalytic activity of the metal-organic complexes containing Lewis acidic metal ions, a test reaction using gly-ser dipeptides was performed in aqueous solution. As a reference, $5.0 \mathrm{~mL}$ of a $2 \mathrm{mM}$ solution of dipeptide in distilled water was prepared and stirred for $24 \mathrm{~h}$ at $70^{\circ} \mathrm{C}$.

For the paramagnetic compound Ce-DO3A- $\mathrm{C}_{4}-\mathrm{SO}_{3}(6 \mathrm{i})$, an equimolar amount of catalyst dissolved in $5.0 \mathrm{~mL}$ MilliQ- $\mathrm{H}_{2} \mathrm{O}$ was added to $5.0 \mathrm{~mL}$ of a $2 \mathrm{mM}$ aqueous solution of gly-ser dipeptide. ESI- $\mathrm{MS}$ (in $\mathrm{H}_{2} \mathrm{O}$, positive mode) was performed for a qualitative estimation of the afforded cleaved amino acids. For the diamagnetic compounds Sc-DO3A- $\mathrm{C}_{4}-\mathrm{SO}_{3}(6 \mathrm{ii})$ and $\mathrm{Zn}-\mathrm{DO} 3 \mathrm{~A}-\mathrm{C}_{4}-\mathrm{SO}_{3}$ (6iii), the reactions were directly conducted in $\mathrm{D}_{2} \mathrm{O}$. A $5 \mathrm{mM}$ stock solution of gly-ser dipeptide in $\mathrm{D}_{2} \mathrm{O}$ was prepared. The catalysts $(5 \mathrm{mM})$ were added to this solution. The $\mathrm{pD}$ was adjusted with diluted $\mathrm{NaOD}$ solution. For the calculation of the corresponding $\mathrm{pH}$ value, the correction $\mathrm{pD}=\mathrm{pH}+0.4$ was applied. A total volume of $2.0 \mathrm{~mL}$ was chosen for each sample. After stirring for $24 \mathrm{~h}$ at $70^{\circ} \mathrm{C}$, the $\mathrm{pD}$ (resp. $\mathrm{pH}$ ) was checked again and has remained unchanged. Characterization of the reaction products was performed via ${ }^{1} \mathrm{H}-\mathrm{NMR}$ spectroscopy. In the case of $\mathrm{Sc}-\mathrm{DO} 3 \mathrm{~A}-\mathrm{C}_{11}-\mathrm{SH}$ (9ii), an equimolar amount of catalyst dissolved in $5.0 \mathrm{~mL}$ MilliQ- $\mathrm{H}_{2} \mathrm{O}$ was added to $5 \mathrm{~mL}$ of a $2 \mathrm{mM}$ aqueous solution of gly-ser dipeptide. ESI-MS analysis (in $\mathrm{H}_{2} \mathrm{O}$, positive mode) revealed that the catalyst remained intact. For a quantification of the yielded amino acids glycine and serine, ${ }^{1} \mathrm{H}-\mathrm{NMR}$ spectroscopy in $\mathrm{D}_{2} \mathrm{O}$ after removal of the solvent in vacuo and drying of the obtained solid was performed.

Cleavage of BSA proteins. A certain amount of surfactant was added to a $2 \mathrm{mM}$ aqueous BSA solution and the $\mathrm{pH}$ value was set to 6.0 using diluted $\mathrm{NaOH}$ or $\mathrm{HCl}$ solution. The reaction mixture was heated to $60^{\circ} \mathrm{C}$ and stirred for $16 \mathrm{~h}$. The elevated temperature accelerates the kinetics of the cleavage reaction, e. g. by partial unfolding of the large polypeptide structure. After $16 \mathrm{~h}$ of stirring at $60^{\circ} \mathrm{C}$, the reaction mixture was analyzed via SDS-PAGE after it had cooled down to room temperature. Detailed information about the SDS-PAGE analysis are given in the following. The SDS loading buffer solution was composed of a $125 \mathrm{mM}$ Tris-HCl buffer ( $\mathrm{pH} 6.8$ ), $500 \mathrm{mM}$ dithiothreitol (DTT), $0.001 \mathrm{mM}$ bromophenol blue, glycerol, SDS and MilliQ- $\mathrm{H}_{2} \mathrm{O}$. The SDS running buffer contained $25 \mathrm{mM}$ Tris base, $192 \mathrm{mM}$ glycine and $0.1 \%$ SDS (w/v). The stacking gel (4\%) was prepared

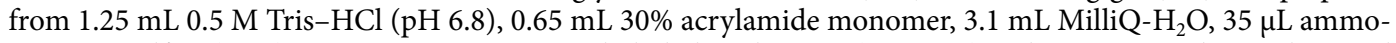
nium persulfate (APS), $5 \mu \mathrm{L} N, N, N^{\prime}, N^{\prime}$-tetramethylethylenediamine (TEMED) and $20 \mu \mathrm{L}$ SDS. The resolving gel (12.5\%) was composed of $2.5 \mathrm{~mL} 1.5 \mathrm{M}$ Tris- $\mathrm{HCl}$ ( $\mathrm{pH}$ 6.8), $4.3 \mathrm{~mL} 30 \%$ acrylamide, $3.3 \mathrm{~mL}$ MilliQ- $\mathrm{H}_{2} \mathrm{O}, 75 \mu \mathrm{L}$ APS, $10 \mu \mathrm{L}$ TEMED and $100 \mu \mathrm{L}$ SDS. The Coomassie stain solution was prepared using a composition of $0.1 \%$ Coomassie Brilliant Blue, $40 \%$ EtOH p. a., 10\% acetic acid glacial and 49.9\% MilliQ- $\mathrm{H}_{2} \mathrm{O}$. The destaining solution consisted of $40 \% \mathrm{EtOH}, 10 \%$ acetic acid glacial and 50\% MilliQ- $\mathrm{H}_{2} \mathrm{O}$. For highly sensitive staining of lower concentrations of polypeptides, a Krypton fluorescent protein stain was used. The excitation emission maximum is $520 \mathrm{~nm}$, the emission maximum is $580 \mathrm{~nm}$. The stain is compatible with excitation light sources of $532 \mathrm{~nm}$ wavelength for in-gel detection. The Krypton stain was commercially available from Thermo Fisher Scientific. Depending on the amount of polypeptide, the time duration of staining was adapted. In brief, the stain (10X stock solution) was diluted ten-fold with MilliQ- $\mathrm{H}_{2} \mathrm{O}$ at $25^{\circ} \mathrm{C}$. Then, having the gels removed from the gel cassette, they were immersed in a tray with sufficient volume of gel fixing solution. After agitating on a shaker for $30 \mathrm{~min}$, the fixing solution was decanted and MilliQ- $\mathrm{H}_{2} \mathrm{O}$ was added carefully to remove residual solution from the gel. Again, the water was decanted and afterwards, the gel was immersed in a sufficient amount of 1X Krypton protein stain and covered using a piece of aluminum foil. The tray was placed on a shaker and stained overnight under smooth agitation. Finally, the stain was decanted and the destaining solution was added. The tray was covered and agitated for further $5 \mathrm{~min}$. The destaining solution was decanted and MilliQ- $\mathrm{H}_{2} \mathrm{O}$ was added. After 
agitation for $15 \mathrm{~min}$, the water was decanted. This process was repeated two times with increasing volumes of MilliQ- $\mathrm{H}_{2} \mathrm{O}$. For the detection of the bands, the gel can be imaged on any platform equipped with appropriate excitation and emission filters. Values are all given in $\mathrm{v} / \mathrm{v}$, unless otherwise stated. The unstained protein standard was commercially available from BioLabs and exhibited a band profile of 10, 15, 25, 30, 40, 50, 60, 70, 85, 100, 120,150 and $200 \mathrm{kDa}$. For the protein analysis via SDS-PAGE, $12.5 \%$ polyacrylamide gels were freshly prepared. Each of the investigated samples was mixed with an equal volume of SDS loading buffer (typically $10 \mu \mathrm{L}$ ) and was afterwards heated to $95^{\circ} \mathrm{C}$ for 5-10 min. Then, after the solutions had come to room temperature, the samples were loaded into the wells. The electrodes were connected to perform the electrophoresis at a constant current of $35 \mathrm{~mA}$. After $25 \mathrm{~min}$, the electrophoresis was finished and the gel was incubated overnight with an appropriate staining solution. The destain solution was added to the gel after the staining process with subsequent rinsing with MilliQ- $\mathrm{H}_{2} \mathrm{O}$ (see above for the exact experimental procedure). After destaining, the gels were stored in a gel storage solution and photographed.

Analytical methods. $\quad 400 \mathrm{MHz}{ }^{1} \mathrm{H}-\mathrm{NMR}$ and $100 \mathrm{MHz}{ }^{13} \mathrm{C}-\mathrm{NMR}$ spectra were recorded on a Bruker Avance III 400 at $298 \mathrm{~K} .600 \mathrm{MHz}{ }^{1} \mathrm{H}-\mathrm{NMR}$ and $125 \mathrm{MHz}{ }^{13} \mathrm{C}-\mathrm{NMR}$ spectra were recorded on a Bruker Avance III 600 at $298 \mathrm{~K} .800 \mathrm{MHz}{ }^{1} \mathrm{H}-\mathrm{NMR}$ and $200 \mathrm{MHz}{ }^{13} \mathrm{C}$-NMR spectra were recorded on a Bruker Avance Neo 800 at 298 K. ESI-MS analysis was performed on a Bruker Microtof II system. The samples were directly injected into the evaporation chamber after syringe filtration using an appropriate solvent. ATR-FT-IR spectra for the investigation of dried solid samples were conducted on a Perkin Elmer Spectrum 100 device using a Perkin Elmer Universal ATR sampling accessory. DLS was measured on a Malvern Zetasizer $\mu V$ at $90^{\circ}$ detection angle. UVVIS measurements were performed on a Thermo Scientific Genesys spectrophotometer using a wavelength range between 190 and $800 \mathrm{~nm}$.

Pendant drop measurements for the determination of the surface tension were performed using KRÜSS ADVANCE 1.8.0.4 software. As second independent method for the measurement of concentration dependent surface tension, commercially available glass capillaries were used in the capillary rise method. TEM was conducted on a Zeiss Libra 120 microscope $(120 \mathrm{kV})$ and HR-TEM on a JEOL JEM-2200FS microscope at $200 \mathrm{kV}$ acceleration voltage. The samples were placed on carbon-coated copper grids (mesh 400).

Received: 28 October 2020; Accepted: 18 February 2021

Published online: 04 March 2021

\section{References}

1. Polarz, S., Kunkel, M., Donner, A. \& Schlotter, M. Added-value surfactants. Chem.-Eur. J. 24, 18842-18856. https://doi.org/10.1002/ chem.201802279 (2018)

2. Scarso, A. \& Strukul, G. Green synthetic processes and procedures 268-288 (The Royal Society of Chemistry, London, 2019).

3. Griffiths, P. C., Fallis, I. A., Chuenpratoom, T. \& Watanesk, R. Metallosurfactants: interfaces and micelles. Adv. Colloid Interface Sci. 122, 107-117. https://doi.org/10.1016/j.cis.2006.06.010 (2006).

4. Dominguez-Gutierrez, D., Surtchev, M., Eiser, E. \& Elsevier, C. J. Ru(II)-based metallosurfactant inverted aggregates. Nano Lett. 6, 145-147. https://doi.org/10.1021/nl051944v (2006).

5. Owen, T. \& Butler, A. Metallosurfactants of bioinorganic interest: Coordination-induced self assembly. Coord. Chem. Rev. 255, 678-687. https://doi.org/10.1016/j.ccr.2010.12.009 (2011).

6. Kaur, R. \& Mehta, S. K. Self aggregating metal surfactant complexes: precursors for nanostructures. Coord. Chem. Rev. 262, 37-54. https://doi.org/10.1016/j.ccr.2013.12.014 (2014).

7. Corma, A. \& Garcia, H. Lewis acids: from conventional homogeneous to green homogeneous and heterogeneous catalysis. Chem. Rev. 103, 4307-4365. https://doi.org/10.1021/cr030680z (2003).

8. Firouzabadi, H. \& Jafari, A. A. Heteropoly acids, their salts and polyoxometalates as heterogenous, efficient and eco-friendly catalysts in organic reactions: Some recent advances. J. Iran. Chem. Soc. 2, 85-114. https://doi.org/10.1007/bf03247201 (2005).

9. Gupta, P. \& Paul, S. Solid acids: green alternatives for acid catalysis. Catal. Today 236, 153-170. https://doi.org/10.1016/j.catto d.2014.04.010 (2014)

10. Su, F. \& Guo, Y. H. Advancements in solid acid catalysts for biodiesel production. Green Chem. 16, 2934-2957. https://doi. org/10.1039/c3gc42333f (2014)

11. Kitanosono, T., Masuda, K., Xu, P. Y. \& Kobayashi, S. Catalytic organic reactions in water toward sustainable society. Chem. Rev. 118, 679-746. https://doi.org/10.1021/acs.chemrev.7b00417 (2018).

12. Okuhara, T. Water-tolerant solid acid catalysts. Chem. Rev. 102, 3641-3665. https://doi.org/10.1021/cr0103569 (2002).

13. Kobayashi, S. \& Manabe, K. Development of novel Lewis acid catalysts for selective organic reactions in aqueous media. Accounts Chem. Res. 35, 209-217. https://doi.org/10.1021/ar000145a (2002).

14. Hermann, S. et al. Magneto-adaptive surfactants showing anti-curie behavior and tunable surface tension as porogens for mesoporous particles with 12 -fold symmetry. Angew. Chem.-Int. Edit. 56, 5475-5479. https://doi.org/10.1002/anie.201612416 (2017).

15. Polarz, S., Baehrle, C., Landsmann, S. \& Klaiber, A. Panoscopic structures by hierarchical cascade self-assembly of inorganic surfactants with magnetic heads containing dysprosium ions. Angew. Chem.-Int. Edit. 52, 13665-13670. https://doi.org/10.1002/ anie.201303565 (2013).

16. Zana, R., Benrraou, M. \& Rueff, R. Alkanediyl-alpha, omega-bis(dimethylalkylammonium bromide) surfactants. 1. effect of the spacer chain-length on the critical micelle concentration and micelle ionization degree. Langmuir 7, 1072-1075. https://doi. org/10.1021/la00054a008 (1991).

17. Zhang, X. \& Wang, C. Supramolecular amphiphiles. Chem. Soc. Rev. 40, 94-101. https://doi.org/10.1039/b919678c (2011).

18. Jagadish, B., Brickert-Albrecht, G. L., Nichol, G. S., Mash, E. A. \& Raghunand, N. On the synthesis of 1,4,7-tris(tertbutoxycarbonylmethyl)-1,4,7,10-tetraazacyclododecane. Tetrahedron Lett. 52, 2058-2061. https://doi.org/10.1016/j.tetle t.2010.10.074 (2011)

19. Ni, J., Sohma, Y. \& Kanai, M. Scandium(iii) triflate-promoted serine/threonine-selective peptide bond cleavage. Chem. Commun. 53, 3311-3314. https://doi.org/10.1039/C6CC10300F (2017).

20. Tseng, C. H. T., Paul, B. K., Chang, C.-H. \& Engelhard, M. H. Continuous precipitation of ceria nanoparticles from a continuous flow micromixer. Int. J. Adv. Manuf. Technol. 64, 579-586. https://doi.org/10.1007/s00170-012-4428-1 (2013). 
21. Bouchaud, B., Balmain, J., Bonnet, G. \& Pedraza, F. pH-distribution of cerium species in aqueous systems. J. Rare Earths 30, 559-562. https://doi.org/10.1016/S1002-0721(12)60091-X (2012).

22. Anderegg, G., Arnaud-Neu, F., Delgado, R., Felcman, J. \& Popov, K. Critical evaluation of stability constants of metal complexes of complexones for biomedical and environmental applications (IUPAC Technical Report). Pure Appl. Chem. 77, 1445-1495. https ://doi.org/10.1351/pac200577081445 (2005).

23. Majkowska-Pilip, A. \& Bilewicz, A. Macrocyclic complexes of scandium radionuclides as precursors for diagnostic and therapeutic radiopharmaceuticals. J. Inorg. Biochem. 105, 313-320. https://doi.org/10.1016/j.jinorgbio.2010.11.003 (2011).

24. Tiddy, G. J. T. Surfactant-water liquid crystal phases. Phys. Rep. 57, 1-46. https://doi.org/10.1016/0370-1573(80)90041-1 (1980).

25. Kobayashi, S. \& Hachiya, I. Lanthanide triflates as water-tolerant lewis acids: activation of commercial formaldehyde solution and use in the aldol reaction of silyl enol ethers with aldehydes in aqueous media. J. Org. Chem. 59, 3590-3596. https://doi.org/10.1021/ jo00092a017 (1994)

26. Manabe, K., Mori, Y., Wakabayashi, T., Nagayama, S. \& Kobayashi, S. Organic synthesis inside particles in water: lewis acidsurfactant-combined catalysts for organic reactions in water using colloidal dispersions as reaction media. J. Am. Chem. Soc. 122, 7202-7207. https://doi.org/10.1021/ja001420r (2000).

27. Kobayashi, S., Nagayama, S. \& Busujima, T. Lewis acid catalysts stable in water: correlation between catalytic activity in water and hydrolysis constants and exchange rate constants for substitution of inner-sphere water ligands. J. Am. Chem. Soc. 120, 8287-8288. https://doi.org/10.1021/ja980715q (1998).

28. Shū, K. \& Kei, M. Green Lewis acid catalysis in organic synthesis. Pure Appl. Chem. 72, 1373-1380. https://doi.org/10.1351/pac20 0072071373 (2000).

29. Yashiro, M. et al. Metal-ion-assisted hydrolysis of dipeptides involving a serine residue in a neutral aqueous solution. Org. Biomol. Chem. 1, 629-632. https://doi.org/10.1039/B209565C (2003).

30. Ly, H. G. T., Absillis, G. \& Parac-Vogt, T. N. Amide bond hydrolysis in peptides and cyclic peptides catalyzed by a dimeric $\mathrm{Zr}$ (iv)substituted Keggin type polyoxometalate. Dalton Trans. 42, 10929-10938. https://doi.org/10.1039/C3DT50705J (2013).

31. Smith, R. M. \& Hansen, D. E. The pH-Rate Profile for the Hydrolysis of a Peptide Bond. J. Am. Chem. Soc. 120, 8910-8913. https ://doi.org/10.1021/ja9804565 (1998).

32. Wezynfeld, N. E., Frączyk, T. \& Bal, W. Metal assisted peptide bond hydrolysis: Chemistry, biotechnology and toxicological implications. Coord. Chem. Rev. 327-328, 166-187. https://doi.org/10.1016/j.ccr.2016.02.009 (2016).

33. Perera-Bobusch, C. et al. Significantly enhanced proteolytic activity of cyclen complexes by monoalkylation. Dalton Trans. 45, 10500-10504. https://doi.org/10.1039/C6DT00681G (2016).

\section{Author contributions}

M.F. conducted the experiments. S.P. designed the research. M.F. and S.P. wrote the manuscript.

\section{Funding}

Open Access funding enabled and organized by Projekt DEAL. The project was performed in cooperation with Henkel AG Düsseldorf. SP thanks the European Research Council (ERC) for funding of a consolidator grant (ISURF project 614606).

\section{Competing interests}

The authors declare no competing interests.

\section{Additional information}

Supplementary Information The online version contains supplementary material available at https://doi. org/10.1038/s41598-021-84654-3.

Correspondence and requests for materials should be addressed to S.P.

Reprints and permissions information is available at www.nature.com/reprints.

Publisher's note Springer Nature remains neutral with regard to jurisdictional claims in published maps and institutional affiliations.

\footnotetext{
(c) (i) Open Access This article is licensed under a Creative Commons Attribution 4.0 International License, which permits use, sharing, adaptation, distribution and reproduction in any medium or format, as long as you give appropriate credit to the original author(s) and the source, provide a link to the Creative Commons licence, and indicate if changes were made. The images or other third party material in this article are included in the article's Creative Commons licence, unless indicated otherwise in a credit line to the material. If material is not included in the article's Creative Commons licence and your intended use is not permitted by statutory regulation or exceeds the permitted use, you will need to obtain permission directly from the copyright holder. To view a copy of this licence, visit http://creativecommons.org/licenses/by/4.0/.
}

(C) The Author(s) 2021 